\title{
MISTÄ MUSIIKKI ALKAA? \\ MUSIIKINHISTORIA JA SEN ALKU MUSIIKKITIETEEN \\ TUTKINTOVAATIMUSKIRJALLISUUDESSA \\ HELSINGIN YLIOPISTOSSA 1923-1975
}

\begin{abstract}
Aika ajoin julkisessa keskustelussa ryöpsähtää esiin väittely musiikinlajien paremmuudesta ja niiden osuudesta julkisessa rahoituksessa. Vuonna 2007 tällainen keskustelu alkoi valtion vientitukien myöntämisestä populaarimusiikille, mikä herätti arvostelua joidenkin klassisen musiikin edustajien keskuudessa. Pianisti, säveltäjä ja kapellimestari Ralf Gothóni kritisoi Helsingin Sanomissa 28.8.2007 sitä, että "kolmesta vaikutusvaltaisimmasta lautakunnasta - säveltaidetoimikunta, ESEK, Suomen Musiikkineuvosto - puuttuu yhtä jäsentä lukuun ottamatta 1000-vuotisen, satojen genrejen musiikkikulttuurin valovoimaisimmat edustajat sekä alan aktiivimuusikot" ja että "huolenpito nykyisinkin voimakkaasti elävästä, satoja ja taas satoja vuosia kehittyneestä musiikkikulttuurista ja ns. nykymusiikista on unohtumassa niiltä henkilöiltä, joiden vastuualueisiin koulutuksen suuntaviivat kuuluvat".

Tästä tuhatvuotisesta musiikkikulttuurista Gothóni käyttää termiä "taidemusiikki", mutta vaihtelevasti sitä on kutsuttu myös termeillä "länsimainen musiikki", "klassinen musiikki" tai jollakin edellisten yhdistelmällä. Intuitiivisesti onkin hyvin helppo hyväksyä argumentti, että traditiota, joka on säilynyt elinvoimaisena 1000 vuotta, ei tule ainakaan kovin kevytmielisesti päästää katoamaan. Samalla voidaan kuitenkin pohtia sitä, miksi tämä traditio yleensä esitetään juuri tuhatvuotisena. Mitä yhteistä on katolisen kirkon yksiäänisellä liturgisella lau-
\end{abstract}


lulla ensimmäisen vuosituhannen lopulla ja nykyisellä sinfoniakonsertilla, jossa hyvin harvoin soitetaan 200 vuotta vanhempaa musiikkia eikä juuri koskaan 300 vuotta vanhempaa? Mikä yhdistää ne traditioksi, jonka tarina on mahdollista kertoa yhdessä kirjassa tai kirjasarjassa, kuten yleisesti tehdään?

Suomalaisen musiikinhistoriankirjoituksen alkuvaiheita tutkineen Matti Huttusen (1993: 31) mukaan "perinteiset länsimaisen taidemusiikin historiat - - kaikki käsittelevät lähes samoja ilmiöitä", mutta on "vaikea löytää mitään yhtenäistä kriteeriä, jolla nämä ilmiöt on valittu". On totta, että taidemusiikin yleishistoriat useimmiten kertovat samoista kanonisoituneista säveltäjistä, teoksista, genreistä ja tapahtumista, eikä niiden valintaprosessia kirjoituksissa yleensä eksplikoida. Mutta koska kertomukset kuitenkin yleensä vaikuttavat sisäisesti koherenteilta ja johdonmukaisilta, on syytä olettaa, että jokin kriteeri on valintaprosessia ohjannut. Yhden ehdotuksen tällaiseksi kriteeriksi tarjoaa Richard Taruskin. Kirjasarjansa The Oxford History of Western Music esipuheessa Taruskin toteaa, että klassisen musiikin kaanon on hyvin heterogeeninen kokoelma erilaisia genrejä, joita kuitenkin yhdistää kirjallinen välittymistapa (Taruskin 2010a: xiv). Tästä syystä "länsimaisen musiikin" tarina alkaa useimmiten nuottikirjoituksen synnystä runsaat tuhat vuotta sitten.

Nuottikirjoitus ei kuitenkaan voi olla ainoa kriteeri. Myös populaarimusiikissa nuotit ja musiikin kirjallinen välittyminen ovat olleet erottamaton osa sen historiaa. Ennen äänilevyjä ansaintalogiikka alalla perustui eläviin esityksiin ja nuottikustanteisiin, aivan samoin kuin klassisessa musiikissa mesenaattijärjestelmän murennuttua. Esimerkiksi vuonna 1892 sävellettyä laulua "After The Ball" myytiin yli viisi miljoona kappaletta - nuotteina. Vasta 1950-luvulla rock'n'rollin myötä musiikki alkoi välittyä useammin äänitteenä kuin kirjallisesti. Tästä huolimatta populaarimusiikki on jäänyt "länsimaisen musiikin" historian ulkopuolelle, aivan viime vuosia lukuun ottamatta. Mielenkiintoista kyllä, myös edellä mainitussa Taruskinin kirjasarjassa populaarimusiikki saa itsenäisen käsittelyn vasta "jälkikirjallisessa" (postliterate), eli rock'n'rollin jälkeisessä vaiheessaan. Syy tähän kaiketi on se, että myös Taruskinin kertomaa tarinaa ohjaa ainakin osaksi kaksi "masterkertomusta", jotka hän mainitsee johdannossaan, mutta joihin hän ei eksplisiittisesti sitoudu. Ensimmäinen on esteettinen kertomus musiikillisten taideteosten lisääntyvästä autonomiasta ja toinen "uushegeliläinen" kertomus edistyksestä ja vapautumisesta ja taideteosten merkityksestä tässä projektissa (Taruskin 2010a: xv). 
Kirjallisen välittymisen merkittävä rooli populaarimusiikin historiassa tekisi toisaalta perustelluksi myös sen, että populaarimusiikin alku sijoitettaisiin nuottikirjoituksen syntyyn. Näin ei tarinaa ole tietääkseni kuitenkaan koskaan kerrottu. Yksikään tarina ei ala gregoriaanisesta kirkkolaulusta ja huipennu Johann Straussiin, "After the Ball:iin" tai Beatlesiin. Useimmiten tarina alkaa 180o-luvun puolivälin tienoilta, joskin poikkeuksia toki on. Esimerkiksi Russell Sanjek, joka tutki amerikkalaisen populaarimusiikkibisneksen historiaa, aloitti tarinansa 1500-luvun arkkiveisumarkkinoista Englannissa (Sanjek 1988).

Artikkelissani tarkastelen sitä, miten musiikin tai musiikkien tarinaa ja ennen kaikkea tarinan alkua on haluttu kertoa yhdelle erityiselle kohderyhmälle, musiikkitieteen opiskelijoille Helsingin yliopistossa 1920-luvulta 1970-luvulle. Mitä musiikinhistoriankirjoja heidän on haluttu lukevan? Mitkä oletukset, aatteet ja arvot ovat vaikuttaneet kirjoissa kerrottuun tarinaan ja sen alkuun? Keskityn yksinomaan Helsingin yliopiston musiikkitieteen tutkintovaatimuksiin, koska kyseisenä ajanjaksona muiden yliopistojen tutkintovaatimukset noudattivat pääasiassa Helsingin esimerkkiä. Tämä johtunee kaiketi siitä, että muiden yliopistojen viranhaltijat olivat saaneet koulutuksensa Helsingissä. Käyn läpi musiikin historiaa käsittelevät kirjat ja hahmottelen muutokset, jotka liittyvät tarinan aloitukseen. Erityistä huomiota kiinnitän kirjoihin, jotka kertovat tarinaa yhdestä yhtenäisestä traditiosta tai musiikkikulttuurista, kuten "taidemusiikista", "länsimaisesta musiikista", "klassisesta musiikista", "kansallisesta musiikista" tai "musiikista" yleensä. Johtopäätösten tekemisessä sovellan tutkimussuuntausta, jossa historiankirjoitusta tutkitaan kertomuksina.

\section{Historian narratologia}

Historian narratologia (historiographical narratology) on tutkimussuuntaus, jossa historiankirjoitusta tutkitaan ennen kaikkea kertomuksina. Tutkimiseen sovelletaan samoja kirjallisuudentutkimuksen käsitteitä ja menetelmiä, joilla aiemmin on tutkittu fiktiivisiä kertomuksia, kuten romaaneja. Merkittävin ero aiempaan historiankirjoituksen tutkimukseen on näkemys, jonka mukaan referenssi ja totuus eivät ole ainoita aspekteja, joilla historiankirjoitusta tulee arvioida. (Ks. esim. Mink 1978: 143-147; Danto 1985: 148-153; Rigney 2002: 11-18; Munslow 2007: 42; Pikkanen 2012: 40-43.) 
Referenssiä ja totuutta tulee etsiä lähinnä yksittäisistä tosiasiaväittämistä. Tällainen on esimerkiksi väite, että syksyllä 1882 Robert Kajanus, Waldemar Klärich ja Nikolai Sinebrychoff perustivat yhdistyksen nimeltä Helsingfors Orkesterförening. Historiankirjoitus ei kuitenkaan koostu pelkästään tosiasiaväittämistä. Voimme toki laittaa niitä peräkkäin kronologiseen järjestykseen esimerkiksi seuraavasti:

- Keväällä 1827 Helsinkiin perustettiin Musikaliska öfningssällskapet

- Syksyllä 1827 perustettiin Musikaliska sällskapet i Helsingfors

- 1844 perustettiin Symfoniföreningen

- 1849 perustettiin Akademiska Orkesterföreningen

- 1860 Nya Teaternin yhteyteen perustettiin orkesteri, jonka johtajaksi tuli Filip von Schantz

- Soitantokausina 1863-1867 teatterin orkesteria johti August Meissner

- Soitantokautena 1868-1869 teatterin orkesteria johti C.G.R. Littmarck

- Syksyllä 1869 perustettiin Orkesterbolaget

- Orkesterbolagetin orkesteria johti soitantokauden 1869-1870 Richard Faltin

- Orkesterbolagetin orkesteria johti soitantokaudet 1870-1878 Nathan B. Emanuel

- Syksyllä 1879 perustettiin Helsingfors Konsertorkester

- Syksyllä 1882 perustettiin Helsingfors Orkesterförening

Tämä ei kuitenkaan ole historiankirjoitusta vaan kronikka. Historiankirjoitukseksi kronikka muodostuu vasta, kun tapahtumien ja asioiden välille luodaan yhteyksiä. Yhteydet antavat tapahtumille merkityksen, ja yhteyksien luominen edellyttää juonellista kertomusmuotoa. Historia on siis juonten luomista ja niiden ymmärtämistä (Ricoeur 1984: 174). Merkityksiä historialliseen kertomukseen eivät luo pelkästään tosiasiaväittämät historiallisista tapahtumista, vaan myös se, miten ne juonen avulla esitetään ja toisiinsa liitetään. Historiallisessa kertomuksessa myös muoto on sisältöä - lähtökohta, joka ilmenee jo suuntauksen klassikon Hayden Whiten artikkelikokoelman nimessä The Content of the Form (White 1987).

Jos siis kirjoitamme seuraavasti, kuten Erkki Salmenhaara kirjoitti Suomen musiikin historia -teoksessa, olemme kertomuksen lähteillä: 
Robert Kajanus (1856-1933) toteutti sen, mitä Helsingissä 1830-luvulta lähtien puoli vuosisataa oli eri tavoin yritetty: perusti vakituisen, ammatillisesti toimivan sinfoniaorkesterin, joka nykyään tunnetaan Helsingin kaupunginorkesterina (Dahlström \& Salmenhaara 1995: 493).

Salmenhaara luo yhdessä virkkeessä yhteyksiä sekä aiempiin että myöhempiin tapahtumiin. Hän viittaa aiempiin orkesterihankkeisiin. Niistä Kajanuksen perustama orkesteri erosi siinä, että se oli vakituinen. Samalla hän viittaa tuleviin tapahtumiin. Kuten Salmenhaara itsekin toteaa, ei "ollut mitään takeita siitä, että [Kajanuksen orkesterihanke] johtaisi aiempaa pysyvämpiin tuloksiin" (Dahlström \& Salmenhaara 1995: 493). Vakituiseksi orkesteria ei tehnyt sen perustaminen 1882, vaan myöhemmät tapahtumat. Lopullisesti toiminta vakiintui vasta, kun orkesteri kunnallistettiin Helsingin kaupunginorkesteriksi 1914 ja soittajista tuli kaupungin virkamiehiä. Luomalla juonellisen kertomuksen Salmenhaara on nostanut Kajanuksen orkesterin perustamisen 1882 muita orkesterihankkeita tärkeämmäksi, ja antanut tapahtumalle merkityksen Helsingin kaupunginorkesterin syntymänä.

Samat tosiasiaväittämät voivat olla mukana monenlaisissa historiallisissa kertomuksissa. Riippuen siitä, minkälaisia tapahtumia kertomuksessa otetaan esille, missä järjestyksessä ne esitetään ja minkälaisia yhteyksiä niiden välille luodaan eli miten tarina juonellistetaan - saavat samat tosiasiat erilaisia merkityksiä. Aivan kuten fiktiivisestä romaanista, voidaan myös historiallisesta kertomuksesta totuuden ohella arvioida sen koherenssia: muodostavatko esille nostetut tapahtumat ja niiden välille luodut yhteydet johdonmukaisen tarinan, jolla on alku, keskikohta ja loppu. Sen sijaan, että kysyisimme onko totta, että Helsingin kaupunginorkesteri perustettiin 1882, ehkä relevantimpaa on kysyä, muodostaako kertomus sen perustamisesta ja historiasta koherentin ja johdonmukaisen kokonaisuuden?

Erilaisia juonirakenteita ei kuitenkaan ole yhtä paljon kuin on erilaisia kertomuksia, vaan monet kertomukset noudattavat perustaltaan samankaltaista juonirakennetta. Tietyt samat tapahtumat nostetaan esille ja niiden välille luodaan tietyt samankaltaiset yhteydet. Kajanuksen orkesterin perustaminen syksyllä 1882 ja sen selkeä ero aiemmista orkesterihankkeista on olennainen osa Suomen musiikin kansalliskertomusta. Salmenhaarakin toteaa, että "[m]usiikinhistoriamme aikakirjat eivät väsy toistamasta tämän pioneerityön merkitystä" (Dahlström \& Salmenhaara 
1995: 493). Helsingin kaupunginorkesterin tutkijoilla olisi toki ollut muitakin vaihtoehtoja tarinan kertomiseen. Jos olisi haluttu korostaa orkesteritoiminnan jatkuvuutta Helsingissä, orkesterin syntyhetkeksi olisi voinut valita vuosi 1860, jonka jälkeen Helsingissä on joka soitantokaudella toiminut julkisia konsertteja antanut ammattimainen jousiorkesteri. Jos taas kaupungin antama tuki olisi toiminut kriteerinä, vuosi 1888 olisi ollut perustamiselle ratkaiseva, koska tuolloin kaupunki ensimmäisen kerran antoi orkesterille avustuksen. Kaupungin organisaatioiden ja instituutioiden tutkija olisi puolestaan voinut valita perustamisvuodeksi 1914, jolloin orkesteri kunnallistettiin. Se, että perustamisvuodeksi vakiintui 1882, johtuu pääasiassa Robert Kajanuksen asemasta fennomaanisessa historiankirjoituksessa.

Kertomuksesta toiseen toistuvista juonirakenteista Krijn Thijs (2011) käyttää termiä master narrative. Termin alkupuoli master voidaan ymmärtää ainakin kolmella eri tavalla. Master voi tarkoittaa herraa, jolla on alaisia. Esimerkiksi Yhdysvaltain eteläosien puuvillaplantaaseilla orjat kutsuivat omistajaansa nimellä massa (master). Master voi tarkoittaa myös oman alansa mestaria tai opettajaa. Musiikissa opettajaa kutsutaan usein italiankielisellä termillä maestro. Lisäksi master voi tarkoittaa painoalan masteria, josta valmistetaan muotit, joilla lopullinen kuluttajalle tarkoitettu tuote painetaan. Esimerkiksi fyysinen CD-levy tehdään ns. lasimasterista valmistetuista muoteista puristamalla. (Thijs 2011: 65-69.) Koska suomenkielessä ei ole sanaa, joka kattaisi kaikki nämä kolme merkitystä, olen päätynyt käyttämään sekakielistä ilmaisua masterkertomus.

Masterkertomus antaa sitä noudattaviin kertomuksiin juonirakenteen eli eräänlaisen narratiivisen luurangon. Keskeistä näissä rakenteissa ovat tietyt käännekohdat, tapahtumat, joihin jokin päättyy tai jokin alkaa. Ehkä kaikkein keskeisin käännekohta on se, mistä koko tarina alkaa. Alku ei tarkoita sitä, että ennen sitä ei olisi mitään, vaan sitä, että ennen alkua ei ole mitään, mitä olisi tarinan kannalta syytä kertoa (Ricoeur 1984: 38).

Myös musiikinhistoriankirjoituksessa halu muodostaa johdonmukaisia ja koherentteja tarinoita on ollut keskeinen, mikä ei ole jäänyt musiikinhistoriankirjoituksentutkijoilta huomaamatta (ks. esim. Dahlhaus 1983: 40-46; Treitler 1999: 361-362; Huttunen 1993: 32-33; Sarjala 2002: 111-118). Musiikin tarinan alkua jäljitän seuraavaksi Helsingin yliopiston musiikkitieteen tutkintovaatimusten musiikinhistorian kirjoista. 


\section{Universaalis-evolutionistinen musiikinhistoria}

Musiikkitieteen opetus Suomessa alkoi 1901, kun Ilmari Krohn aloitti luennoimisen Keisarillisen Suomen Aleksanterin-Yliopiston (myöh. Helsingin yliopisto) musiikin historian ja teorian dosenttina. Ensimmäiset tutkintovaatimukset painettiin kuitenkin vasta lukuvuodeksi 1923-1924. Ne olivat kokonaisuudessaan seuraavat (tässä, kuten myöhemminkin artikkelissani, olen noudattanut painettujen tutkintovaatimusten suomenkielistä kirjoitusasua, tosin korostuksia yhtenäistäen ja ilmeisimpiä kirjoitusvirheitä korjaillen):

\section{Approbatur.}

- H. Klemetti: Musiikin historia (julkaisemattomien loppuosien sijalle vastaavat luvut M. Wegeliuksen "Länsimaiden musiikin historiasta").

- I. Krohn: Musiikin teorian oppijakso. I. Rytmioppi. II. Säveloppi. III. Harmoniaoppi. (Pelkästään analyysi-harjotuksineen).

- Sävellysmuodot ja soittimet (esim. H. Leichentritt: Musikalische Formenlehre tai M. Wegelius: Yleinen musiikkioppi ja analyysi, II).

- K. Grunsky: Musikästhetik (Sammlung Göschen).

Cum laude approbatur. (edellisen lisäksi):

- T. Norlind: Svensk musikhistoria (kursoorisesti).

- H. Kretzschmar: Geschichte der Oper.

- A. Schweitzer: J. S. Bach.

- E. Schmitz: Musikästhetik.

- I. Krohn: Rytmi- ja Sävelopin sävellys- y.m. harjotukset.

Laudatur. (edellisen lisäksi):

- I. Krohn: Harmoniaopin sävellys- y.m. harjotukset, sekä Musiikin teorian oppijakso IV. Kontrapunkti (kunnes se on julkaistu, joku muu vastaava teos, Bussler, Bellermann y.m.).

- Analyysi jostakin sävelteoksesta, sopimuksen mukaan.

- Valmistava aines-suoritus (esim. sävelmäkokoelma meloodisesti järjestettävä tahi vanhemman ajan suomalainen musiikkikäsikirjoitus kopioitava ja nykynuotteihin muutettava). 
- Kirjallinen tutkielma (laudatur-kirjoitus) ynnä siihen kohdistuvia erikoisteoksia (2 tai 3), sopimuksen mukaan.

Rajan vetäminen musiikinhistorian ja muun musiikintutkimuksen välillä ei ole mitenkään yksiselitteistä (ks. Huttunen 1993: 4-8). Vaikka esimerkiksi soitinopin kirjat painottuvat yleensä nykyaikaan ja soitinten nykymuotoon, sisältävät ne usein myös lyhyempiä tai pidempiä katsauksia soitinten historiaan. Vuoden 1923 tutkintovaatimuksista on kuitenkin helppo poimia viisi kirjaa, joissa musiikinhistoria on keskeinen sisältö. Heikki Klemetin kirja (julkaistu alun perin 1916) ja Martin Wegeliuksen kirjasarja (julkaistu alun perin kolmessa osassa ruotsiksi 1891-1893 ja yhdessä osassa suomeksi 1904) kertoivat musiikin yleisestä historiasta, Tobias Norlindin teos (1901, toinen laitos 1918) oli kansallinen musiikinhistoria, Hermann Kretzschmarin kirja (1919) genren historia ja Albert Schweitzerin kirja (1908, englanniksi 1911) säveltäjäbiografia.

Huomionarvoista on, että musiikin yleisen historian alkupäätä opiskeltiin Klemetin kirjasta, ei Wegeliuksen kirjasarjasta Hufvuddragen af den västerländska musikens historia från den kristna tidens början till våra dagar I-III. Syy tähän on mitä ilmeisimmin se, minkä Klemetti kirjansa esipuheessa mainitsee Wegeliuksen kirjan pahimmiksi puutteiksi. Ensiksikin Wegeliuksen kirjassa on varsin vähän nuottiesimerkkejä ja toiseksi "kokonaan puuttuu siitä esitys luonnonkansain, kaukaismaisten ja vanhan ajan sivistyskansain musiikista" (Klemetti 1916: v). Ulkoeurooppalaisen musiikin poisjättämistä Wegelius perustelee seuraavasti:

Musiikkia ammon ajoista on taiteena viljelty arialaisten kansojen keskuudessa. Sanomme taiteena - joskin aivan yksinkertaisessa ja alkuperäisessä merkityksessä - sillä se ei olisi voinut miellyttää, saati sitte voittaa niin suurta valtaa kaikkien mielissä, ellei se olisi ollut sopusoinnussa kaikille yhteisten vaistojen kanssa, tahi toisin sanoin ollut muodostunut yleishyvien, luonnonomaisten perusteiden mukaan. Näiden kansojen, ihmisellisen sivistyksen luojien ja kantajien mukana musiikki levisi yli maailman, ja pysyi voimassa - niin kuin muukin sivistys niin kauan ja siinä määrässä kuin arialaisen aineksen vaikutus kesti. Missä tämä rotujen sekaantuessa menetti voimansa ja katosi tahi vain heikkona pysyttelihe vierasten joukkojen keskuudessa, siellä alkoi musiikkikin taantua. Siten Europan ulkopuolella asuvien kansojen musiikki on joko jäänyt alemmalle, kehittymättö- 
mälle asteelle (Arabia ja India), tahi kehittynyt nurjaan, luonnottomaan suuntaan (Kiina, Jaappani). Tällaisen musiikin tutkiminen voi sentähden meidän aikaiselle säveltaiteilijalle tahi taiteen ystävälle tarjota ainoastaan kansatieteellistä, vaan ei elävää asiallista mielenkiintoa. (Wegelius 1904: 4, kursiivi alkuperäisessä.)

Klemetti (1916: v) sen sijaan on sitä mieltä, että näiden ulkoeurooppalaisten musiikissa "kansatieteellisen mielenkiinnon lisäksi tapaamme monta länsimaisenkin musiikin alkukehitystä valaisevaa piirrettä".

Vaikka Wegelius ja Klemetti olivatkin hyvin erimielisiä ulkoeurooppalaisen musiikin merkityksestä ja asemasta musiikin historiassa, siitä he olivat yhtä mieltä, että musiikki kehittyy ja edistyy, ja tässä kehityksessä länsimainen musiikki edustaa huippua. Koska musiikin historia on osa ihmiskunnan universaalia historiaa, kaikki maailmassa soitettu ja soitettava musiikki kaikkina aikoina on laitettavissa yhdelle ja samalle evoluutiojanalle ja arvioitavissa suhteessa siihen. Kristillisessä teologiassa kirkkoisä Augustinuksesta lähtien ihmiskunnan jakamattomuuden ja sen historian yhtenäisyyden takasi Jumala luomalla ensimmäisen ihmisen, Aatamin, josta kaikki muut ihmiset polveutuivat. 16oo-luvulta lähtien tämä käsitys maallistui ja Jumalan tilalle "ensimmäisenä prinsiippinä" ihmiskunnan yhtenäisyyden takeeksi tuli "luonto", "henki", "sivilisaatio", "dialektiikka" tai jokin muu maallinen lähtökohta. (Nisbet 1969, 63-64.) Ihmiskunnan yhteisen historian vuoksi kaikilla yhteiskunnallisilla instituutioilla musiikki mukaan lukien on yhteinen alkuperä.

Musiikinhistorian juonellistaminen yhdeksi universaalis-evolutionistiseksi kehityskertomukseksi tapahtui 1700-luvun loppupuolella. 1600-luvun oppineille ei ollut olemassa yhtä musiikkia vaan erilaisia rinnakkain eläviä musiikillisia käytäntöjä, joiden väliltä puuttui kehitys tasolta toiselle. Musiikin kategorisointi tapahtui pääasiassa musiikin funktion mukaan, eikä esimerkiksi musiikillisen materiaalin kehitysasteen tai säveltäjän elinvuosien mukaan. 1700-luvun lopun musiikinhistorian yleisesityksissä (esim. Charles Burney 1776-1789, Sir John Hawkins 1776, J.N. Forkel 1788-1801) sen sijaan oli olemassa vain yksi musiikki, joka asteittain ja vaiheittain kehittyi kohti aikakautensa länsimaista musiikkia. (Allen 1962: 11, 70, 184, 228.)

180o-luvun loppupuolelle tultaessa evoluutioteoriat olivat vallitsevia kaikissa ihmistieteissä. Usein on viitattu biologi Charles Darwiniin ja hänen kirjoihin- 
sa On the Origin of Species (1859) ja The Descent of Man (1871) näiden teorioiden suurimpina innoittajina ja vaikuttajina (ks. Bock 1955: 123). Wegeliuskin siteeraa Darwinin jälkimmäistä teosta kirjansa johdannossa. 180o-luvun lopun biologisella evolutionismilla ja ihmistieteiden sosiaalievolutionismilla on kuitenkin varsin vähän tekemistä toistensa kanssa. Biologinen evoluutioteoria (varsinkin darwinilaisessa muodossaan) perustuu tilastollisiin metodeihin ja populaatioteorioihin, kun taas sosiaalievoluutiolle keskeistä on typologioiden luonti. Biologisessa evoluutiossa todellisia toimijoita ovat biologiset yksilöt, joita voidaan kollektiivisesti kuvata ainoastaan tilastollisin menetelmin populaatioina. Sosiaalievoluutiossa subjekteja puolestaan ovat yhteiskuntaluokka, kansakunta, kulttuuri tai mikä muu tahansa vastaava tyyppi, joihin ihmisyksilöiden toimintaa voidaan luokitella. (Nisbet 1969: 162.)

Sosiaalievoluutio ei perustu darwinismiin, vaan paljon vanhempaan biologiseen metaforaan: biologisen organismin kasvuun. Kun yhteiskunnallisessa kirjoittelussa on viitattu kulttuurin, yhteiskunnan tai yhteiskunnallisen instituution kasvuun ja kehittymiseen, on sillä jo antiikin Kreikasta lähtien tarkoitettu kasvua orgaanisessa merkityksessä. Orgaaninen kasvu ei ole satunnaista ja summittaista, vaan suuntautunutta, kumulatiivista, peruuttamatonta, vaiheittaista ja tarkoituksenmukaista. Se on myöskin sisäsyntyistä ja luonnollista: kaikki kasvun kannalta olennainen informaatio sisältyy jo siemeneen, josta kasvu saa alkunsa. Luonnonmukainen kasvu on siemeneen sisältyvän potentiaalin toteutumista. Näin myös sosiaalievoluutiossa. Kulttuurin tai instituution syntyhetkellä kaikki sen keskeiset ominaisuudet ovat jo "iduillaan" kehittyäkseen vaiheittain nykyiseen tilaansa. Tästä syystä sosiaalievolutionistisessa masterkertomuksessa tarinan alku on tarinan tärkein elementti. (Bock 1955: 130-131; Bock 1966: 277; Nisbet 1969: 7-11, 160-165; ks. myös Allen 1962: 237-239; Treitler 1984: 365.) 180o-luvun lopulla ja 1900-luvun alussa erilaisten kulttuuristen instituutioiden (avioliitto, sukulaisuus, uskonto, yksityisomaisuus, musiikki) alkuperän selvittäminen olikin kehittyvien ja eriytyvien yhteiskuntatieteiden keskeisimpiä tehtäviä.

Jos kasvu ja kehitys pysähtyy tai kääntyy "epäluonnolliseen" suuntaan, johtuu se sosiaalievolutionistisen masterkertomuksen mukaan ympäristötekijöistä. Wegeliuksen ja Klemetin olennaisesti toisistaan poikkeavia näkemyksiä musiikin varhaishistoriasta selittääkin juuri se, missä ja miten heidän mielestään musiikki 
on syntynyt ja mikä on musiikin "luonnollinen" kehityssuunta. Wegeliuksen näkemyksiä ohjasi voimakas usko arjalaiseen rotuoppiin. Hänen mukaansa arjalaiset ovat "ihmisellisen sivistyksen luojia ja kantajia", joiden musiikki on muodostunut "luonnonomaisten perusteiden mukaan" ja on näin ollen "sopusoinnussa kaikille yhteisten vaistojen kanssa". Kehityksen pysähtyminen tai kääntyminen "nurjaan, luonnottomaan" suuntaan on johtunut muiden rotujen vaikutuksesta, ja koska niillä näin ollen on vain "kansatieteellistä arvoa", Wegelius ei käsittele niitä ollenkaan. Arjalaisen rodun musiikinhistorian hän aloittaa antiikin kreikkalaisista. (Wegelius 1904: 4.)

Sen sijaan Klemetille, kuten lähes kaikille muillekin evolutionistisen paradigman kannattajille tuona aikana, ulkoeurooppalaisen musiikin tutkimus, samoin kuin eurooppalaisen kansanmusiikin tutkimus, oli musiikin universaalihistorian tutkimusta. Päinvastoin kuin Huttunen antaa ymmärtää, Klemetin lähestymistavan universaalisuus ei ollut poikkeuksellista eikä kansanmusiikin tutkimuksen ja musiikin "varsinaisen historiografian" välillä ollut jyrkkää rajaa, jos rajaa ollenkaan (ks. esim. Huttunen 1993: 8, 30-31, 75, 79). Melkeinpä kaikkien varhaisten suomalaisten musiikintutkijoiden (Krohn, Klemetti, Launis, Väisänen jne.) tutkimusintresseihin kuului yhtä lailla niin sanottu länsimainen taidemusiikki kuin kansanmusiikkikin - kuten Euroopassa yleisemminkin. Sen sijaan poikkeuksellista oli Wegeliuksen arjalaisesta rotuteoriasta ammentamansa olematon mielenkiinto eurooppalaista kansanmusiikkia ja ulkoeurooppalaista musiikkia kohtaan. Mitä todennäköisimmin juuri tämä oli syynä siihen, että yleisen musiikinhistorian alkuvaiheita opiskeltiin Klemetin eikä Wegeliuksen kirjasta.

\section{Vertaileva Metodi}

Totta kylläkin on, että musiikinhistorian yleisesitysten laatijat, Klemetti mukaan lukien, hyvin harvoin itse tutkivat ulkoeurooppalaisia musiikkikulttuureja. Philip Bohlmanin mukaan suhtautumisessaan ei-länsimaiseen musiikkiin 180o-luvun musiikintutkimus jakautui kahteen vaiheeseen. Vuosisadan alkupuolta luonnehti ei-länsimaisen musiikin löytäminen ja sen tutkimuksen aloittaminen. Vuosisadan loppupuolella musiikinhistorioitsijat integroivat ei-länsimaisen mu- 
siikin osaksi musiikinhistoriaa: "Ambrosille ja muille musiikinhistorioitsijoille 180o-luvun toisella puoliskolla musiikin historian kirjoittaminen ei ollut enää länsimaisen musiikin, vaan kaiken musiikin kehityksen esiintuomista". (Bohlman 1987: 148, 153.) Ambrosin musiikinhistorian kirjasarjan koko ensimmäinen osa keskittyykin kokonaisuudessaan muinaisten kulttuurikansojen ja luonnonkansojen musiikkiin. Eurooppalaiseen musiikkiin päästään vasta neliosaisen kirjasarjan toisessa osassa (Ambros 1862-1878).

Ulkoeurooppalaisen musiikin integrointi osaksi musiikin universaalihistoriaa tapahtui 180o-luvun keskeisen tieteellisen lähestymistavan, Vertailevan Metodin avulla. Vertaileva Metodi, jota eri tavoin hyödynsivät esimerkiksi Auguste Comte, Karl Marx, Herbert Spencer, Edward B. Tylor ja Lewis Morgan, perustuu kolmen sarjan synkronointiin. Ensimmäinen sarja on nykyhetkellä elävät kansat ja heidän sosiaaliset organisaationsa sekä käden ja hengen tuotteet loogis-spatiaalisesti järjestettynä. Eri kansojen kulttuuriset tuotteet ja instituutiot (sukulaisuus, uskonto, sotiminen jne.) järjestetään loogiseen järjestykseen yksinkertaisemmasta monimutkaisempaan. Toinen sarja on ajallinen. Historiallinen ja arkeologinen data järjestetään aikajanalle, joka ulottuu ajassa niin kauas taaksepäin, kuin dataa on löydettävissä. Koska aikajana on rajallinen eikä ulotu esimerkiksi sukulaisuuden, uskonnon ja sotimisen syntyhetkiin, tarvitaan vielä kolmas sarja: evoluutiosarja. Kaksi edellistä sarjaa järjestetään peräkkäisiin kehitystasoihin. Yhteiskunnat kokonaisuudessaan asetetaan evoluutiojanalle kehittymättömästä kehittyneempään tai jonkin yhteiskunnallisen instituution (sukulaisuus, uskonto, sotiminen jne.) kehitys sen syntyhetkistä nykypäivään abstrahoidaan kahden ensimmäisen sarjan tuottaman datan perusteella. (Nisbet 1969: 191, 195-196; ks. myös Allen 1962: 231-237.)

Ulkoeurooppalaisten kansojen tutkimus oli Vertailevassa Metodissa ennen kaikkea ihmiskunnan universaalihistorian tutkimista. Ulkoeurooppalaisten kansojen tapojen, instituutioiden ja kulttuurituotteiden tutkimuksella pyrittiin pääsemään aikajanalla historiallisen ja arkeologisen datan tarjoamien todisteiden tuolle puolen. Vertailevan Metodin kolmannen sarjan taustalla oli ajatus samanaikaisuuden eriaikaisuudesta (ks. esim. Fabian 1983). Vaikka Ceylonin Weddakansa lauloi laulujaan samaan aikaan kun Euroopan metropoleissa esitettiin Beethovenin sinfonioita, evoluutioaikajanalla Wedda-kansan laulut sijoittuivat janan alkupäähän, Beethovenin sinfoniat janan loppupäähän. 
Entä mitkä olivat musiikin evoluutioasteen arviointikriteerit? Minkälainen musiikki sijoittui evoluutiojanan alkupäähän ja minkälainen sen loppupäähän? Klemetille tärkeimmät kriteerit olivat soittimien määrä ja melodioissa käytettävien sävelten määrä, eli kuinka monesta erilaisesta nuoteilla ilmaistavasta sävelkorkeudesta melodia muodostuu (ks. myös Huttunen 1993: 77). Hän toteaa, että luonnonkansain musiikillinen kehitystaso vaihtelee:

Toisilla on monenlaisia, melkoista kehitystä todistavia soittimia ja sävelmiä, jotka lähentelevät sivistyskansojen kansanlauluja, toiset taas eivät tunne ainuttakaan soitinta ja supistuu heidän musiikinharjoittamisensa aivan alkeelliseen lauluun, jossa vain paria, korkeintaan kolmea säveltä toistellaan (Klemetti 1916: 1).

Klemetti asettaa eksplisiittisesti luonnonkansojen melodiat ja sivistyskansojen kansanlaulut samalle evoluutiojanalle, jossa edelliset lähestyvät jälkimmäisiä, näitä kuitenkaan saavuttamatta. Sävelkorkeudeltaan kiinteät ja erilliset sävelet, niiden määrä ja suhde toisiinsa olivat oli ylipäätään evolutionistisessa musiikinhistorian paradigmassa keskeisimmät kriteerit musiikin kehitysastetta arvioitaessa. Esimerkiksi kirjassaan Handbuch der Musik-Geschichte vuodelta 1868 Arrey von Dommer kirjoittaa, että "luonnolta musiikki ei saanut muuta kuin epäorgaanisen äänen; ensimmäinen tehtävä ihmiselle oli kiinteän sävelkorkeuden käsitteen luominen ja sen jälkeen eri äänien järjestäminen suhteessa toisiinsa. Kaikki tämä oli tehtävä, ennen kuin raaka-aineella [äänellä] saattoi olla minkäänlaista taiteellista merkitystä" (sit. Allen 1962: 120). Charles Parry kirjoitti puolestaan vuonna 1893 kirjassaan Evolution of the Art of Music, että "musiikin kehityksen pohjalla ovat ne villien huudot, joissa ei ole juuri lainkaan erillisiä säveliä" (sit. Allen 1962: 228).

Klemetti käsittelee kirjassaan ensin luonnonkansojen musiikin, tämän jälkeen "kaukaismaisten" sivistyskansojen (kiinalaisten, japanilaisten, intialaisten ja arabialaisten) musiikin, sitten vanhan ajan sivistyskansojen (babylonialaisten, assyrialaisten, egyptiläisten, hebrealaisten ja kreikkalaisten) musiikin, ennen kuin hän ryhtyy tarkastelemaan varhaiskristillistä kirkkolaulua. 


\section{Metodologinen nationalismi ja kansalliskertomus}

Toinen 180o-luvun merkittävä aatesuunta evolutionismin ohella oli nationalismi. Sen lisäksi, että se poliittisena ideologiana ja kansallistunteena jakoi maailmaa kansallisvaltioihin, sen vähemmän tunteenomainen muoto vaikutti yhteiskuntatieteelliseen ja humanistiseen tutkimukseen. Metodologisessa nationalismissa kansakunta ja kansallisvaltio ovat tutkimuksen perusyksiköitä, joiden sisällä ja joiden välillä tutkimusta tehdään. Maailman "jakautuminen kansakunniksi kutsuttuihin toimijoihin - - näyttäytyy todellisuuden rakentumisen olennaisena ja oikeana periaatteena" (Kettunen 2008: 16).

Metodologisessa nationalismissa toimijoita ovat yksilöiden ohella kansakunnat ja yksilöitäkin käsitellään usein kansan ja kansanhengen edustajina. Tämä näkemys käy erittäin selkeästi ilmi Albert Schweitzerin Bach-biografiasta.

\footnotetext{
Bach oli päätepiste. Hänestä ei mikään ala, vaan häneen kaikki päättyy. Hänen todellisen elämänkertansa kertominen vaatii selontekoa saksalaisen taiteen ominaispiirteistä ja kehityksestä, mikä hänessä saa täyttymyksensä. [--] Tämä nerous ei ollut yksilöllinen vaan kollektiivinen henki. (Schweitzer 1966 [1908]: 3-4.)
}

Myös Wegeliuksen kirjasarjassa metodologinen nationalismi on sisältöä keskeisesti muovaava lähtökohta. Wegelius jakaa musiikinhistorian kansallisiin "suuntiin", jotka eri aikoina erilaisin painoarvoin ovat edistäneet musiikin universaalia kehitystä.

Metodologiseen nationalismiin olennaisesti liittyvä, mutta sen poliittisempi ja tunteenomaisempi muoto historiantutkimuksessa on nationalistinen masterkertomus, jota ytimekkäämmin myös kansalliskertomukseksi kutsutaan.

Kansalliskertomus on yksinkertaisesti tarina, jota (kansallinen) yhteisö kertoo itsestään. Se kertoo kansakunnan muodostaville yksilöille (ja kaikille muille kiinnostuneille) keitä he ovat, mistä heidän (kansallinen, yhteinen) menneisyytensä koostuu, mitkä ovat heidän yhteisölliset ominaisuutensa ja mihin he ovat menossa - eli miten heidän tulisi toimia politiikan alueella. (Yadgar 2002: 58.) 
Musiikillisessa kansalliskertomuksessa juonellisesti tärkeimpiä tapahtumia ovat kansallisten musiikillisten instituutioiden perustaminen, tärkeimpänä kansallinen sävelkieli. On syytä kuitenkin huomata, että myös musiikillinen kansalliskertomus on ennen kaikkea kielellinen, ei musiikillinen kertomus. Kertomus tarvitsee sankareikseen musiikillisia toimijoita, mutta heidän toimintansa kansallisen merkityksen selittäminen on tutkijoiden, historioitsijoiden, kirjailijoiden ja kriitikkojen tehtävä. Tästä on hyvänä esimerkkinä Sibeliuksen Kullervon kansallisen merkityksen konstruointi lehdistössä ja tutkimuskirjallisuudessa (ks. Heikkinen 2012).

Musiikillisen kansalliskertomuksen alku sijoittuu useimmiten kansakunnan alkuvaiheisiin, siten kuin ne historiallisen ja arkeologisen lähdeaineiston perusteella ovat rekonstruoitavissa. Toisin kuin musiikinhistorian yleisesityksissä, joissa musiikin alkuvaiheita etsitään luonnonkansoja vertaamalla niiden maantieteellisestä sijainnista riippumatta, kansalliskertomuksessa keskeistä on alueellinen ja kansakunnallinen rajaus. Tämä ei välttämättä kuitenkaan täysin sulje pois Vertailevan Metodin käyttöä. Myös Tobias Norlind kirjassaan Svensk musikhistoria, joka vuoden 1923 tutkintovaatimuksissa edusti kansalliskertomusta, viittaa kirjansa alussa vertailuun eri kansojen välillä. Musiikin varhaisimpia vaiheita hän etsii Skandinavian alueelta löydetyistä pronssikautisista torvista ja valittaa kansanomaisten instrumenttien löytöjen vähyyttä, mikä tekee vertailun muiden kansojen välillä mahdottomaksi. Myöhemmin Norlind rajaa käsittelynsä Ruotsin valtakunnan alueeseen ja "korkeamman musiikinviljelyn" pariin. Pronssikautisten torvien lisäksi hänen kertomuksessaan ei ole sijaa muulle kansanomaiselle musisoinnille.

Lukuun ottamatta muutamaa viittausta Turun musiikkielämään Norlind ei käsittele Suomea Ruotsin valtakunnan osana, vaikka tämä historiallinen yhteys varmaankin oli syy, miksi kirja tutkintovaatimuksissa oli. Suomalainen kansalliskertomus musiikista oli vasta muovautumassa. Se liittyy myöhemmin tehtyihin tutkintovaatimusten muutoksiin, joita seuraavaksi käsittelen.

\section{Muutokset tutkintovaatimuksissa 1928-1960}

Ennen 1960-lukua muutokset tutkintovaatimuksissa olivat vähäisiä, eikä vaatimuksia painettu läheskään joka lukuvuonna erikseen. Tentittävien kirjojen määrä lisääntyi vähitellen. Esimerkiksi Hermann Kretzschmarin oopperahistorian lisäk- 
si piti vuodesta 1951 lähtien tenttiä Karl Nefin Geschichte der Symphonie und Suite (1921). Samana vuonna mukaan alkoi tulla vaihtoehtoja. Jos ei halunnut tenttiä Albert Schweitzerin Bach-elämänkertaa, oli mahdollista tenttiä Paul Bekkerin Beethoven-elämänkerta (1911, ruotsiksi 1916).

Universaalihistorian alkuvaiheita opiskeltiin Heikki Klemetin kirjasta vuoteen 1951. Klemetti oli suunnitellut kirjasarjastaan kolmiosaista ja toinen osa ilmestyikin 1926. Tästä huolimatta 1500-luvun jälkeistä musiikin historiaa opiskeltiin Wegeliuksen kirjoista. Syynä tähän mitä ilmeisimmin oli Ilmari Krohnin ja Klemetin erimielisyys napolilaisen suuntauksen merkityksestä musiikinhistoriassa (ks. Huttunen 1993: 87). Vuonna 1936 tutkintovaatimuksiin lisättiin Klemetin ja Wegeliuksen kirjojen ohelle uudemman musiikin aukkoa paikkaamaan 1933 julkaistu Sulho Rannan suppeahko Musiikin historia pääpiirteittäin. Kuten Klemetti, myös Ranta edusti sosiaalievolutionismia ja Vertailevaa Metodia.

\footnotetext{
Kaikkein varhaisimman, esihistoriallisen ajan musiikki ei luonnollisesti voi saada kuvaustaan. Sen selvittämisessä on lähdettävä jonkinlaisesta oletetusta todellisuusnäkökohdasta: tarkasteltava maapallollamme vielä eläväin luonnonkansojen musiikkia. (Ranta 1933: 7)
}

Tässä paradigmassa "luonnonkansat" ja heidän tapansa ja kulttuurituotteensa ovat eräänlaisia jäänteitä ihmiskunnan yhteiseltä alkutaipaleelta (ks. Hodgen 1931). Kertomuksensa Ranta aloittaa kuitenkin vielä kauempaa, "säveltaiteen" syntyhetkestä, jonka hän asettaa "viettielämän, jokapäiväisen työn tai korkeampia voimia palvovan kultin yhteyteen" (Ranta 1933: 10).

Vuoden 1951 tutkintovaatimuksissa Sulho Rannan kirja vaihdettiin hänen edellisvuonna ilmestyneeseen laajennettuun laitokseen Musiikin historia 1. Aikaisempaa teostaan, jonka sisällöstä puolet käsitteli 1800- ja 1900-lukua, Ranta oli laajentanut musiikin historian varhaisempiin vaiheisiin. Kirja edusti edelleenkin vahvasti sosiaalievolutionistista näkemystä. Kuten Klemetti aiemmin, Ranta käy ensin läpi luonnonkansojen, itämaisten sivistyskansojen, Etu-Aasian sivistyskansojen ja antiikin kreikkalaisten musiikin.

Rannan uusi kirja teki Klemetin kirjan tarpeettomaksi ja se poistettiin vaatimuksista. Samalla poistettiin Wegeliuksen kirjat ja tilalle otettiin Gunnar Jean- 
sonin ja Julius Raben kaksiosainen kirjasarja Musiken genom tiderna (1927-1931). Jeansonin ja Raben kirjassa sosiaalievolutionismi on jo häivytetty taustalle:

\begin{abstract}
Musiikki on ikivanha taidemuoto, joka juontaa juurensa ihmiskunnan historian varhaisista vaiheista. Siellä, minne inhimillinen kulttuuri on levinnyt, on varmasti ollut myös musiikkia. Säveltaiteen kehitysvaiheiden seuraaminen luonnonkansojen ja vieraiden kulttuurien piirissä onkin laaja ja toistaiseksi suureksi osaksi mahdoton tehtävä, joka vieläkin tarjoaa loputtomasti ratkaisemattomia ongelmia. Tämän esityksenkään tarkoitus ei ole johdattaa lukijaa ikivanhoihin aikoihin tai etäisiin kulttuurialueisiin. (Jeanson \& Rabe 1927: 1, käännös Tuula Kotilainen ja Hannele Branch.)
\end{abstract}

Kirjoittajat tekevät saman ratkaisun kuin Wegelius teki aiemmin: musiikilla on yksi ja yhtenäinen historiansa ihmiskunnan kehityksessä, mutta sen varhaisvaiheet he jättävät kertomatta. Kertomuksensa he aloittavat antiikin Kreikan musiikkielämästä tehden kuitenkin sen varauksen, että "on varottava - - korostamasta liian voimakkaasti yhtymäkohtia antiikin kulttuuriin muiden kustannuksella" (Jeanson \& Rabe 1927: 9). Jeanson ja Rabe korostavatkin länsimaisen kristillisen kulttuurin uutuutta suhteessa antiikkiin - heille kyseessä oli siis ennen kaikkea uusi kulttuuri. Tämä näkökulma tuli korostumaan 196o-luvun tutkintovaatimuksissa.

Norlindin Svensk musikhistoria oli käytössä vuoteen 1962. Sen rinnalle lisättiin Suomen musiikinhistoriaa koskevia kirjoituksia sitä mukaa, kun niitä saatiin julkaistua. Vuoden 1931 vaatimuksiin lisättiin Toivo Haapasen artikkeli "Säveltaide" vuodelta 1925 ja Ilmari Krohnin artikkeli "Suomalaiset kansansävelmät" vuodelta 1928. Haapasen artikkeli edustaa sekä metodologista nationalismia että tunnepohjaista kansallismielisyyttä puhtaimmillaan:

Säveltaiteemme - - on saavuttanut kypsyyden, omintakeisuuden ja laajuuden, joka omassa maassa on kohottanut sen arvoa sivistystekijänä ja myöskin kansojenvälisessä musiikinviljelyksessä hankkinut sille merkitystä. (Haapanen 1925: 408.)

Nationalistisessa näkemyksessä keskipisteenä on siis kansallinen musiikkielämä kokonaisuutena, ja sen merkitystä ja kehitysastetta arvioidaan suhteessa muiden kansojen musiikkielämän merkitykseen ja kehitysasteeseen. 
Mutta miten kansallinen ja universaali, jotka tarkemmin analysoimatta saattavat tuntua jopa toisilleen vastakkaisilta, sidotaan musiikinhistoriankirjoituksessa yhteen? Strategioita on useita ja sama teksti saattaa hyödyntää useampaakin strategiaa. Yksi mahdollisuus on turvautua laskeutuvien kulttuuriainesten hypoteesiin (gesunkenes Kulturgut). Tämän hypoteesin mukaan alempien kansankerrosten kulttuuri on ylempien kansankerrosten kulttuurin jäljittelyä, jossa "kulttuurituotteet yksinkertaistuvat, karkeistuvat ja saavat alkuperäisestä poikkeavia merkityksiä" (Knuuttila 1994: 26). Ajatus perustuu 1900-luvun alun elitismiin, jossa kunkin "[a]ikakauden yleinen henki pyrittiin johtamaan henkisesti johtavien kerrosten hengentuotteista" (Peltonen 1992: 48). Näin ollen "kansankulttuurissa ilmenevät henkiset pyrinnöt ja saavutukset voidaan johtaa korkeakulttuurin piiristä" (Knuuttila 1994: 26). Jos siis kansallinen kulttuuri on sivistyneistön universaalin korkeakulttuurin jäljittelyä, kansallinen on jo lähtökohtaisesti universaalia, joskin sen kansallinen ja korruptoitunut muoto.

Laskeutuvien kulttuuriainesten hypoteesia soveltavat sekä Heikki Klemetti että Ilmari Krohn, joskin varsinkin Klemetti on muotoiluissaan melko varovainen. Klemetin mukaan varhaiset kristilliset kirkkosävelmät "hedelmöittivät kansanmusiikin, joka sitten syrjäisemmillä seuduilla on uskomattomalla sitkeydellä nämä kirkolliset piirteet säilyttänyt" (Klemetti 1916: 73). Mutta, vaikka "[k]irkollisten mallien mukaan kehittyi epäilemättä suuri osa varhaisemman keskiajan maallisiakin sävelmiä", niin "huomioon on otettava myös näiden suoranainen vaikutus maasta maahan." (Klemetti 1916: 77-78; ks. myös Huttunen 1993: 79.) Krohn on asiasta hiukan varmempi kuin Klemetti. Hänen mukaansa "[y]hä varmemmaksi käy se käsityskanta, jonka mukaan kansansävelmäin tyyliainekset ovat jätteitä entisaikoina ylempien kansankerrosten käyttämästä taidemusiikista" (Krohn 1928: 499).

Myös Haapanen kirjoittaa, että "rungot kaikessa kansanmusiikissa useinkin lienevät kansainvälistä yhteisomaisuutta", joihin kunkin "kansan oma tuntemistapa" painaa leimansa (Haapanen 1925: 409-410). Haapanen tuntuu kuitenkin tarkoittavan tällä ainoastaan kansanmusiikin uusimpia kerrostumia. Sen sijaan hän korostaa "muinaisuuden hämärään" ulottuvan suomalaisen kansanmusiikin "hedelmöittävää" vaikutusta nykyaikaiseen säveltaiteeseen (Haapanen 1925: 408). Toinen strategia kansallisen ja universaalin integroimisessa on orgaanisen kasvun metaforan mukaisesti esittää kansanmusiikki länsimaisen taidemusiikin "hedel- 
möittäjänä". Erityisen selvänä tämä strategia on läsnä Haapasen kirjassa Suomen säveltaide (1940), joka vuoden 1951 vaatimuksissa korvasi hänen suppeamman artikkelinsa. Haapaselle musiikillinen toiminta on "viljelyä" ja viljeltävä kasvi on "Suomen musiikkielämä" tai "Suomen säveltaide". (Viljelymetafora oli tuohon aikaan hyvin yleinen ja sitä käyttivät runsaasti myös Wegelius, Klemetti ja Norlind.)

Haapaselle Suomen säveltaiteen "juuret" ovat toisaalta keskiaikaisessa kirkkolaulussa, toisaalta kalevalaisessa runoudessa. Länsimaisen musiikin traditio on "kasvattanut maaperän" ja omista kansallisista "lähteistä" se on "ammentanut ydinvoimansa" (Haapanen 1940: 5). Kertomuksensa hän aloittaa kristillisen kirkkolaulun saapumisesta Suomeen. Kansanmusiikki tulee kertomukseen mukaan 170o-luvun lopulla kansanrunouden ja -musiikin keräyksen myötä. Siitä eteenpäin kansanmusiikki avaa uusia "lähteitä", joista "virtaa tuoreita vaikutteita" (Haapanen 1940: 37). "Kypsyyden" viljeltävä kasvi, eli Suomen kansallinen musiikkielä mä saavuttaa 180o-luvun lopulla, kun Helsinkiin perustetaan musiikkiopisto ja orkesteri ja Sibelius luo suomalaisen säveltaiteen (Haapanen 1940: 80, 99).

Kolmas strategia kansallisen ja universaalin integroimisessa on samaistaa ne keskenään. Tämä oli tyypillistä ennen kaikkea saksalaisessa musiikkikirjoittelussa. Esimerkiksi Lorenz Kraussold kirjoitti vuonna 1876, että "Wagnerin nationalismi on laadultaan universaalia, koska universaalisuus on yksi saksalaisen kansallistunteen tunnusomaisimpia piirteitä" (sit. Allen 1962: 119). Tätä strategiaa ei kuitenkaan tapaa niissä kirjoissa, joista suomalaiset musiikkitieteen opiskelijat musiikinhistoriaa opiskelivat.

\section{Musiikin historiasta musiikkien historioihin}

Vuonna 1962 Sulho Rannan Musiikin historia 1 jäi pois ja Donald Groutin kirja $A$ History of Western Music (1960) tuli vaihtoehdoksi Jeansonin ja Raben teokselle. Kokonaisuudessaan vuoden 1962 tutkintovaatimukset olivat seuraavat:

Approbatur.

- Jeanson-Rabe, Musiken genom tiderna tai D.J. Grout, A History of Western Music. 
- Toivo Haapanen, Suomen säveltaide- Karl Ekman, Jean Sibelius.

- A.O. Väisänen, Kansanmusiikki (Suomen kulttuurihistoria IV).

- A.O. Väisänen, Kalevalan sävelmä (Kalevalaseuran vuosikirja 29).

- Eino Linnala, Yleinen musiikkioppi I-II.

- Ilmari Krohn, Musiikin teorian oppijakso. I. Rytmioppi, ilman harjoituksia.

- Osallistuminen pienoismuotojen ja sointujen analyysiharjoituksiin (yksi lukukausi kumpaakin).

Cum laude approbatur. Edellinen oppijakso sekä:

- Teoksesta Sohlmans Musiklexikon Norjaa, Ruotsia ja Tanskaa käsittelevät yleisartikkelit sekä lisäksi Nordraakia, Griegiä ja Valenia, Romania, Berwaldia, Stenhammaria ja Rosenbergiä ynnä Gadea ja Nielseniä käsittelevät erikoisartikkelit.

- A. Schweitzer, J.S. Bach tai Philipp Spitta, Joh. Seb. Bach.

- A.Einstein, Mozart tai Bernhard Paumgartner, Mozart.

- Paul Bekker, Beethoven.

- H.J. Moser, Musikästhetik.

- K. Nef, Geschichte der Symphonie und Suite.

- D.J. Grout, A Short History of Opera I-II.

- Curt Sachs, Handbuch der Musikinstrumentenkunde tai Tobias Norlind, Musikinstrumentens historia.

- E. Roiha, Johdatus musiikkipsykologiaan.

- Wegelius-Linnala, Kenraalibasso (kirjoitusharjoitukset).

- Eino Linnala, Soinnutuksen perusteet, luvut I-XI harjoituksineen sekä Ilmari Krohn, Musiikinteorian oppijakso III Harmoniaoppi, luku II, kohdat J ja K (ss. 197-230, muunne- ja vaihdesoinnut).

- I. Krohn, Musiikinteorian oppijakso V Muoto-oppi.

- Osallistuminen seminaariharjoituksiin ja niissä pidetty esitelmä.

Laudatur. Edellisen oppijakso sekä:

- Karl H. Wörner, Musik der Gegenwart tai A. Salazar, Music in our Time.

- Eino Linnala, Soinnutuksen perusteet, luvut XIII-XxIv harjoituksineen.

- Knud Jeppesen, Kontrapunkt (tansk. tai saks.) 2-, 3-, ja 4-ääninen asettelu.

- Seminaariesitelmä. 
- Tieteellinen tutkielma (laudaturtyö) ja siihen liittyviä erikoisteoksia sopimuksen mukaan.

Groutin kirjassa tehdään jo otsikkotasolla se linjaus, mikä sisältyy implisiittisesti Jeansonin ja Raben kirjaan. Grout keskittyy länsimaisen musiikin historiaan, vielä tarkemmin ilmaistuna länsimaisen taidemusiikin historiaan, kuten kirjoittaja johdannossa rajaa. Poissa ovat luonnonkansat ja itämaiset sivistyskansat. Grout tekeekin kirjansa johdannossa selkeän linjauksen:

Sukupolvi aiemmin tämän kirjan nimi olisi ollut yksinkertaisesti Musiikin historia. Tämän päivän näkemys on erilainen, ja sana "länsimainen" otsikossa heijastaa sitä tosiasiaa, että läntisen Euroopan ja Amerikan musiikillinen systeemi on ainoastaan yksi monista maailman sivilisaatioiden joukossa. (Grout 1960: xiii.)

Vaikka näitä muita sivilisaatioita ja niiden musiikillisia järjestelmiä ei tutkimusvaatimuksissa vielä otettu huomioon, perusta niiden mukaan tulolle oli valettu. Länsimaisen taidemusiikin ulkopuolista musiikkia edusti ainoastaan kaksi A.O. Väisäsen artikkelia suomalaisesta kansanmusiikista.

Vuonna 1968 musiikkitieteen arvosanat jaettiin neljään osa-alueeseen: musiikin historiaan, musiikin tuntemukseen, musiikin teoriaan ja musiikin tutkimukseen. 1970 tämä jako yksinkertaistettiin vastaamaan Guido Adlerin jo 180o-luvun lopulla tekemää jakoa historialliseen ja systemaattiseen osaan. Samalla tehtiin tutkintovaatimuksissa täysi remontti. Arvosanojen historialliset osat sisälsivät seuraavat kirjat:

Approbatur.

- D.J. Grout, A History of Western Music, Karl H. Wörner, Geschichte der Musik tai Jacques Handschin, Musikgeschichte im Ueberblick. Materiaaliin tutustuttava myös kuuntelun avulla erillisten ohjeiden mukaan.

- Toivo Haapanen, Suomen säveltaide ja Seppo Nummi, Modern musik (Finland i dag), Nils-Eric Ringbom, Sibelius (Musik in Geschichte und Gegenwart). Perehtyminen valikoimaan suomalaista musiikkia erillisten ohjeiden mukaan; tukiteoksena Kai Maasalo, Suomalaisia sävellyksiä IIII. 
- Teoksesta Sohlmans Musiklexicon Norjaa, Ruotsia ja Tanskaa käsittelevät yleisartikkelit sekä Nordraakia, Griegiä ja Valenia, Romania, Berwaldia, Stenhammaria ja Rosenbergiä ynnä Gadea ja Nielseniä käsittelevät erikoisartikkelit.

Cum laude approbatur.

- Erkki Salmenhaara, Vuosisatamme musiikki tai Eric Salzman, Twentieth Century Music. Lisäksi Ton de Leeuw, Nittonhundratalets musik tai H.H. Stuckenschmidt, Musik des 20. Jahrhunderts sekä Håkan Sandblad, Popmusik - extas, revolt och industri. Materiaaliin perehdyttävä myös kuuntelun avulla erillisten ohjeiden mukaan.

- Kahden edustavan säveltäjän perusteelliset monografiat. Esim. Karl G. Fellerer, Palestrina, Leo Schrade, Monteverdi, Albert Schweitzer, Bach, Alfred Einstein, Mozart - sein Charakter, sein Werk (on myös ruots.), Paul Bekker, Beethoven, Alfred Einstein, Schubert, Karl H. Wörner, Schumann, Arthur Hedley, Chopin, Ernest Newman, Wagner as Man and Artist, Norman Del Mar, Richard Strauss, Edward J. Dent, Ferruccio Busoni, Erik Tawaststjerna, Jean Sibelius, Heinrich Strobel, Debussy, Halsey Stevens, Bartók, Israel Nestiev, Prokofjev, Roman Vlad, Stravinsky. Materiaaliin perehdyttävä myös kuuntelun avulla erillisten ohjeiden mukaan.

\section{Laudatur.}

- Vaihtoehtoisesti a) Paul Henry Lang, Music in Western Civilisation, b) Gustave Reese, Music in the Middle Ages, c) Gustave Reese, Music in the Renaissance, d) Manfred F. Bukofzer, Music in the Baroque Era, e) Friedrich Blume, Music in the Classic Era (valmisteilla), f) Alfred Einstein, Music in the Romantic Era, g) Paul Collaer, La musique moderne (on myös saks. ja engl.) tai Peter Yates, Twentieth Century Music sekä Jan Maegaard, Musiikin modernismi, h) Donald J. Grout, A Short History of Opera sekä Joseph Kerman, Opera as Drama, i) Bo Wallner, Vår Tids music I Norden, j) Gunther Schuller, Early Jazz sekä Leroy Ostransky, The Anatomy of Jazz. Materiaaliin perehdyttävä myös kuuntelun avulla erillisten ohjeiden mukaan. 
- Kahden edustavan säveltäjän perusteelliset monografiat (eri teokset kuin cum laude -kurssissa, voidaan valita kohdasta 9). Asianomaisten säveltäjien teoksiin perehdyttävä myös kuuntelun avulla erillisten ohjeiden mukaan.

Musiikinhistorian kannalta merkittävintä oli se, että Groutin kirjassaan mainitsemat ei-eurooppalaiset musiikilliset järjestelmät saivat ensi kerran paikkansa, ei evoluutiojanan alkupään edustajina, vaan itsenäisinä musiikkikulttuureina, joilla oli oma musiikillinen "systeeminsä". Mielenkiintoista kyllä, William P. Malmin kirjaa Music Cultures of the Pacific, the Near East, and Asia (1967) ei sijoitettu historialliseen vaan approbaturin systemaattiseen osaan. Malmin kirja oli vaihtoehtoinen Bruno Nettlin kirjan Folk and Traditional Music of the Western Continents (1965) kanssa. Lisäksi samassa kohdassa piti tenttiä Erkki Ala-Könnin artikkeli "Suomen kansanmusiikki" artikkelikokoelmasta Kansantaide ja perinnepolitiikka (1969). Ei-eurooppalaiset musiikkikulttuurit, samoin kuin eurooppalainen ja länsimainen kansanmusiikki, eivät jääneet pois ainoastaan evoluutiojanalta, ne jäivät kokonaan historiattomiksi. Sen sijaan jazzmusiikkia käsittelevät Schullerin ja Ostranskyn kirjat sekä Sandbladin popmusiikkia käsittelevä kirja sijoitettiin historialliseen osaan. Vuoden 1975 tutkintovaatimuksissa myös Malmin ja Nettlin kirjat siirrettiin historialliseen osaan.

Jazz-, populaari- ja kansanmusiikkia käsittelevät uudet tenttikirjat korostivat musiikkikulttuuriensa erillisyyttä länsimaisen klassisen musiikin traditiosta. Malm (1977: 3) toteaa yksiselitteisesti, että "aboriginaalien musiikkia ei voi verrata Beethovenin sinfonioihin, koska niillä ei ole keskenään mitään tekemistä" ja että "musiikki ei ole kansainvälinen kieli; se koostuu kokonaisesta sarjasta yhtä loogisia, mutta erillisiä järjestelmiä". Schuller (1968: x) puolestaan kirjoittaa, että "jazz on yksi monista musiikillisista kielistä ja kulttuureista, jotka meillä 190o-luvun puolivälissä on käytettävissä".

On huomattava myös yksi pieni, mutta merkityksellinen muutos tutkintovaatimusten terminologiassa. Kun vuoden 1970 vaatimuksissa edellytetään perehtymistä "valikoimaan suomalaista musiikkia erillisten ohjeiden mukaan", vuoden 1975 vaatimuksissa edellytetään perehtymistä "valikoimaan suomalaista taidemusiikkia erillisten ohjeiden mukaan" (korostus lisätty). Länsimainen taidemusiikki ja muut musiikkikulttuurit erkaannutettiin erillisiksi järjestelmiksi, joilla kullakin oli oma historiansa ja oma alkunsa (ks. myös Nettl 2010: 50). 


\section{Johtopäätökset}

Edellä esitelty kehitys musiikkien historioista yhden musiikin historiaan ja siitä takaisin useiden musiikkien historioihin vastaa kehitystä humanistisissa ja yhteiskuntatieteissä yleisemminkin. Historiasta yleensä erotuksena yksittäisten subjektien (kuninkaiden, valtakuntien, kirkon jne.) historioista alettiin puhua vasta 1780-luvulla. Historiasta tuli "kollektiivisingulaari", käsite, joka kokosi yhteen kaikki yksittäiset historiat. (Koselleck 2004: 194-195.) Ihmiskunnan yhteisen historian selvittäminen ei kuitenkaan ollut yksinomaan historiantutkijoiden tehtävä vaan pikemminkin päinvastoin: $1800-$ luvun alusta lähtien ammattimaiset historiantutkijat pyrkivät lähteisiin pohjautuen selvittämään historiaa "siten, kuin se todella tapahtui". Yleisesityksiä ihmiskunnan alkuhämärästä nykypäivään laativat yleensä muut kuin ammattihistorioitsijat. Esimerkiksi antropologia oli syntyessään historiaan suuntautunut tieteenala (Harris 1968: 1).

Robert A. Nisbet (1969: 30-32) erottaakin toisistaan jyrkästi "historiallisen" ja "luonnonhistoriallisen" lähestymistavan menneisyyteen. "Historiallisessa" lähestymistavassa keskeisiä ovat henkilöt ja tapahtumat, jotka voidaan ajoittaa tiettyyn historialliseen aikakauteen, vuoteen tai päivämäärään. Tämä traditio alkaa antiikin tunnetuista historioitsijoista Herodotuksesta ja Thukydideksestä ja ulottuu uuden ajan Edward Gibboniin ja Leopold von Rankeen. "Luonnonhistoriallisessa" lähestymistavassa keskeistä on yhteiskunnan tai yhteiskunnallisen instituution "luonnonmukaisen" kehityksen selvittäminen ja kertominen sen synnystä aina nykyhetkeen. Olennaista eivät ole tarkasti ajoitettavat ja peräkkäin sijoitettavat tapahtumat, vaan muutokset, joiden kautta idullaan ollut potentiaali on luontonsa mukaisesti realisoitunut. Tämä traditio alkaa Aristotelesta ja ulottuu Karl Marxiin ja Herbert Spenceriin. "Luonnonhistoriallinen" lähestymistapakaan ei väheksy tarkasti ajoitettavissa olevaa dataa - tästä Marxin kirjoitukset ovat hyvänä esimerkkinä - mutta henkilöt ja tapahtumat ovat alisteisia luonnonmukaisen kehityksen selvittämiselle ja kertomiselle. "Luonnonhistoriallista" näkemystä edustaa muun muassa käsitys, jossa säveltäjää tai sävellystä pidetään ajastaan edellä tai ajastaan jäljessä olevana. Käytännössä tarkan rajan tekeminen "historiallisen" ja "luonnonhistoriallisen" lähestymistavan välille voi olla vaikeaa (Ricoeur 1984: 162). Varmaa kuitenkin on, että edellä luetelluista musiikinhistorian oppikirjoista ainakin Wegeliuksen, Klemetin ja Rannan kirjat noudattavat 
"luonnonhistoriallista" sosiaalievolutionistista masterkertomusta, joka on ohjannut kertomuksen juonellistamista.

Syy sosiaalievolutionistisen universaalihistoriankirjoituksen päättymiselle oli Vertailevan Metodin mahalasku humanistisissa ja yhteiskuntatieteissä toisen maailmansodan jälkeen (ks. Bock 1966). On vaikea osoittaa yhtä nimenomaista syytä uskon horjumiseen, mutta epäilemättä kaksi maailmansotaa ja varsinkin holokausti saattoivat läntisen maailman ylivertaisuuden evoluutioketjussa kyseenalaisiksi. Vertailevan Metodin lähtökohta oli yksiselitteisen etnosentrinen: vertailun tuloksena muodostettu loogis-spatiaalinen sarja alkoi poikkeuksetta siitä, mikä oli mahdollisimman ei-eurooppalaista (esim. Wedda-kansan musiikki), ja eteni kohti sitä, mikä oli mahdollisimman tyypillisesti eurooppalaista (esim. Beethoven). Sosiaalievolutionistien ensisijainen tavoite ei ollut universaalihistorian kirjoittaminen sinänsä, vaan sen selvittäminen, miten ja miksi heidän länsimaisesta yhteiskunnastaan ja kulttuuristaan oli tullut sellainen kuin se on. (Bock 1966: 274-276.)

Vertailevan metodin paradigmatappio 1950-luvulla näkyi myös musiikintutkimuksessa. Vaikka usein korostetaan jatkumoa vertailevasta musiikkitieteestä sotien jälkeiseen etnomusikologiaan, paradigman vaihto oli huomattava. Antropologisesti orientoituneet ja Vertailevan Metodin hylänneet etnomusikologit eivät enää pyrkineet löytämään perusteita länsimaisen musiikin ylivertaisuudelle, vaan he tutkivat musiikkia osana kunkin kulttuurin funktionaalista systeemiä. (ks. esim. Stone 2008: 37-45; Nettl 2010: 66, 96-98, 120.) Samalla musiikinhistorian yleisesityksistä tuli länsimaisen musiikin historian yleisesityksiä, kuten Donald Grout edellä olevassa sitaatissa linjasi. Samalla kun ulkoeurooppalainen musiikki menetti historiallisen merkityksensä, se menetti vähäksi aikaa kaiken merkityksensä musiikkitieteen oppiaineessa. Ainakin tutkintovaatimusten valossa 1960-luvulla Helsingin yliopistossa musiikkitieteen opiskelu oli lähes kokonaan länsimaisen taidemusiikin opiskelua. Muutos tähän tuli vuosikymmenen lopulla.

Mitä lähemmäksi nykyhetkeä tulemme, sitä vaikeammaksi muodostuu tenttikirjallisuuden perusteella arvioida, minkälaista käsitystä musiikinhistoriasta musiikkitieteen opiskelijoille tarjotaan. Sen lisäksi, että tutkintovaatimusten kirjallisuusluettelot sisältävät paljon vaihtoehtoja, löytyy vaihtoehtoja myös opintojaksojen suorittamistavoissa. Lisäksi aiemmin hankitun osaamisen tunnistamisen ja tunnustamisen käytäntö (АНОт) mahdollistaa yliopiston ulkopuolella tehdyn suorituksen hyväksi lukemisen. Kun vielä 1940-luvulla kaikki tenttivät samat 
kirjat, nykyisin maisterin tutkintoon tähtäävä opintopolku voi olla hyvinkin erilainen eri opiskelijoiden välillä.

Mielenkiintoista ja ehkäpä tulevaisuuden kannalta oireellista on se, että Groutin kirjan A History of Western Music kahdeksanteen painokseen (2010), joka sisältyy tämän hetkisten perusopintojen opintojaksoon "Johdatus länsimaisen taidemusiikin historiaan", on lisätty jazzia ja populaarimusiikkia käsittelevät luvut. Tutkintovaatimuksissa nämä luvut on tosin rajattu opiskeltavan alueen ulkopuolelle. Kirjan kahdeksannen painoksen toimittaja J. Peter Burkholder perustelee populaarimusiikkitraditioiden käsittelyä sillä, että nämä traditiot ovat olennainen osa musiikkikulttuuria ja merkittäviä sinällään. Lisäksi ne ovat antaneet vaikutteita klassisen musiikin säveltäjille. (Burkholder ym. 2010: 779-780.) Populaarimusiikin historiaa käsittelee myös Richard Taruskin viisiosaisen kirjasarjansa The Oxford History of Western Music (2010b) viidennessä osassa. Hänen mukaansa tämä on tarpeellista, koska nuorisokulttuuriin assosioitunut 196o-luvun populaarimusiikki oli muokkaava voima, joka vaikutti kaikkiin musiikkeihin (Taruskin 2010b: 311).

Kuten Burkholderin ja Taruskinin kirjat osoittavat, suuret kertomukset eivät ole musiikinhistoriankirjoituksesta hävinneet; masterkertomukset vain ovat hieman muuttuneet. Jakolinja klassisen ja muun musiikin välillä on osittain muuttunut jaoksi länsimaisen ja ei-länsimaisen musiikin välillä, ja tässä jaossa klassinen musiikki, jazz ja länsimainen populaarimusiikki ovat samalla puolella. Miten tämä uusi rajanveto tulee vaikuttamaan tutkintovaatimuksiin, jää nähtäväksi. Myöskään nationalistinen historiankirjoitus ei ole loppunut, vaan esimerkiksi 1990-luvun alussa sekä Suomessa (Suomen musiikin historia 1-4, 1995-1996) että Ruotsissa (Musiken i Sverige 1-4, 1992-1994) julkaistiin moniosainen kirjasarja, joissa kohde rajattiin metodologisen nationalismin mukaisesti kansallisvaltion sisään.

Jälkipolvet tulevat selvittämään, minkälaiset masterkertomukset ohjaavat musiikinhistoriankirjoitustamme nykyisin. Varmaa kuitenkin on, että sillä, minkälaisen juonen ja masterkertomuksen valitsemme, on poliittista ja taloudellista merkitystä, kuten artikkelin alussa siteerattu Ralf Gothónin puheenvuoro selkeästi paljastaa. Nostamalla menneisyydestä tiettyjä tapahtumia ja luomalla kertomuksen avulla niiden välille merkityksiä voimme pyrkiä oikeuttamaan toimintamme ja varmistamaan paikkamme resurssienjaossa. Kertomukset ovat vahva ase. 


\section{Lähteet}

Ala-Könni, Erkki (1969) "Suomen kansanmusiikki”. Kansantaide ja perinnepolitiikka. Helsinki: Suomen Kulttuurirahasto.

Allen, Warren Dwight (1962) Philosophies of Music History. A Study of General Histories of Music 1600-1960. New York: Dover.

Ambros, August Wilhelm (1862-1878) Geschichte der Musik. Breslau: Leuckard.

Bekker, Paul (1911) Beethoven. Berlin: Schuster \& Loeffler.

Bock, Kenneth E. (1955) "Darwin and social theory". Philosophy of Science 22, ss. 123-134.

Bock, Kenneth E. (1966) "The comparative method of anthropology". Comparative Studies in Society and History 8: ss. 269-280.

Bohlman, Philip V. (1987) “The European Discovery of Music in the Islamic World and the 'NonWestern' in 19th-Century Music History". The Journal of Musicology 5, ss. 147-163.

Burkholder, J. Peter \& Grout, Donald Jay \& Palisca, Claude V. (2010) A History of Western Music. $8^{\text {th }}$ edition. New York: W.W. Norton.

Dahlhaus, Carl (1983) Foundations of Music History. Transl. J.B. Robinson. Cambridge: Cambridge University Press.

Dahlström, Fabian \& Salmenhaara, Erkki (1995) Suomen musiikin historia 1. Ruotsin vallan ajasta romantiikkaan. Helsinki: wsor.

Danto, Arthur C. (1985) Narration and Knowledge. New York: Columbia University Press.

Fabian, Johannes (1983) Time and the Other. How Anthropology Makes its Object. New York: Columbia University Press.

Grout, Donald Jay (1960) A History of Western Music. New York: W.W. Norton \& Company.

Haapanen, Toivo (1925) "Säveltaide". Suomi. Maa. Kansa. Valtakunta. III. Helsinki: Otava. Ss. 408428.

Haapanen, Toivo (1940) Suomen säveltaide. Helsinki: Otava.

Harris, Marvin (1968) The Rise of Anthropological Theory. A History of Theories of Culture. New York: Thomas Y Crowell Company.

Heikkinen, Olli (2012) "Jean Sibeliuksen Kullervo ja Larin Paraske: tarina suomalaisen sävelkielen synnystä osana kansalliskertomusta". Musiikki 42, ss. 6-26.

Hodgen, Margaret T. "The doctrine of survivals: The history of an idea". American Anthropologist 33, ss. 307-324. 
Huttunen, Matti (1993) Modernin musiikinhistoriankirjoituksen synty Suomessa. Acta Musicologica Fennica 18. Helsinki: Suomen Musiikkitieteellinen Seura.

Jeanson, Gunnar \& Rabe, Julius (1927) Musiken genom tiderna. En popular framställning av den västerlänska tonkonstens historia. Första delen. Stockholm: Hugo Gebers Förlag.

Kettunen, Pauli (2008) Globalisaatio ja kansallinen me. Tampere: Vastapaino.

Klemetti, Heikki (1916) Musiikin historia. I osa. Porvoo: wsor.

Knuuttila, Seppo (1994) Tyhmän kansan teoria. Näkökulmia menneestä tulevaan. Tietolipas 129. Helsinki: sKs.

Koselleck, Reinhart (2004) Futures Past. On the Semantics of Historical Time. New York: Columbia University Press.

Kretzschmar, Hermann (1919) Geschichte der Oper. Leipzig: Breitkopf \& Härtel.

Krohn, Ilmari (1928) "Suomalaiset kansansävelmät". Oma maa. Tietokirja Suomen kodeille. 2. uudistettu painos. Toim. Kaarle Krohn ym. Porvoo: wsor. Ss. 498-514.

Malm, William P. (1977 [1967]) Music Cultures of the Pacific, the Near East, and Asia. $2^{\text {nd }}$ edition. Englewood Cliffs: Prentice-Hall.

Mink, Louis O. (1978) "Narrative form as a cognitive instrument". The Writing of History. Literary Form and Historical Understanding. Toim. Robert H. Canary \& Henry Kozicki. Wisconsin: The University of Wisconsin Press. Ss. 129-149.

Munslow, Alun (2007) Narrative and History. Basingstoke: Palgrave Macmillan.

Nef, Karl (1921) Geschichte der Sinfonie und Suite. Leipzig: Breitkopf \& Härtel.

Nettl, Bruno (1965) Folk and Traditional Music of the Western Continents. Englewood Cliffs: Prentice-Hall.

Nettl, Bruno (2010) Nettl's Elephant. On the History of Ethnomusicology. Urbana: University of Illinois Press.

Nisbet, Robert A. (1969) Social Change and History. Aspects of the Western Theory of Development. Oxford: Oxford University Press.

Norlind, Tobias (1918) [1901] Svensk musikhistoria. Stockholm: Wahlström \& Widstrand.

Peltonen, Matti (1992) Matala katse. Kirjoituksia mentaliteettien historiasta. Helsinki: Hanki \& Jää.

Pikkanen, Ilona (2012) Casting the Ideal Past. A Narratological Close Reading of Eliel AspelinHaapkylä's History of the Finnish Theatre Company (1906-1910). Acta Universitatis Tamperensis 1787. Tampere: Tampere University Press.

Ranta, Sulho (1933) Musiikin historia pääpiirteittäin. Jyväskylä: Gummerus.

Ranta, Sulho (1950) Musiikin historia. Säveltaiteen vaiheiden pääpiirteet. 1 osa. Jyväskylä: Gummerus. Ricoeur, Paul (1984) Time and Narrative. Volume 1. Transl. Kathleen McLaughlin \& David Pellauer. Chicago: University of Chicago Press. 
Rigney, Ann (2002) The Rhetoric of Historical Representation. Three Narrative Histories of the French Revolution. Cambridge: Cambridge University Press.

Sanjek, Russell (1988) American Popular Music and Its Business. The First Four Hundred Years.

Oxford: Oxford University Press.

Sarjala, Jukka (2002) Miten tutkia musiikin historiaa? Tietolipas 188. Helsinki: sKs.

Schuller, Gunther (1968) Early Jazz. Its Roots and Musical Development. New York: Oxford University Press.

Schweitzer, Albert (1966 [1911]) J.S. Bach. Engl. by Ernest Newman. New York: Dover.

Stone, Ruth (2008) Theory for Ethnomusicology. Upper Saddle River: Pearson Prentice Hall.

Taruskin, Richard (2010a) Music from the Earliest Notations to the Sixteenth Century. The Oxford History of Western Music, Volume 1. Oxford: Oxford University Press.

Taruskin, Richard (2010b) Music in the Late Twentieth Century. The Oxford History of Western Music, volume 5. Oxford: Oxford University Press.

Thijs, Krijn (2011) “The metaphor of the master: 'Narrative hierarchy' in national historical cultures of Europe". The Contested Nation. Ethnicity, Class, Religion and Gender in National Histories. Toim. Stefan Berger \& Chris Lorenz. Basingstoke: Palgrave Macmillan. Ss. 60-74.

Treitler, Leo (1984) “What kind of story is history?". 19 $9^{\text {th }}$-Century Music 7, ss. 363-373.

Treitler, Leo (1999) “The historiography of music: issues of past and present". Rethinking Music. Toim. Nicholas Cook \& Mark Everest. Oxford: Oxford University Press. Ss. 356-377.

Wegelius, Martin (1891-1893) Hufouddragen af den västerländska musikens historia från den kristna tidens början till våra dagar I-III. Helsingfors: Holm.

Wegelius, Martin (1904) Länsimaisen musiikin historia pääpiirteissään kristinuskon alkuajoista meidän päiviimme. Suom. Axel Törnudd. Helsinki: K.E. Holm.

White, Hayden (1987) The Content of the Form. Narrative Discourse and Historical Representation. Baltimore: Johns Hopkins University Press.

Yadgar, Yaacov (2002) "From the particularistic to the universalistic: national narratives in Israel's mainstream press, 1967-97". Nations and Nationalism 8, ss. 55-72. 